\title{
ANALISIS EFEKTIVITAS KEDALAMAN GROUTING UNTUK MENINGKATKAN DAYA DUKUNG LATERAL FONDASI TIANG BETON PRACETAK
}

\author{
Fanica $^{1}$ dan Alfred J. Susilo ${ }^{2}$ \\ ${ }^{\text {I} P r o g r a m ~ S t u d i ~ S a r j a n a ~ T e k n i k ~ S i p i l, ~ U n i v e r s i t a s ~ T a r u m a n a g a r a, ~ J l . ~ L e t j e n ~ S . ~ P a r m a n ~ N o .1 ~ J a k a r t a ~}$ \\ Email: fanicaalfan24@gmail.com \\ ${ }^{2}$ Program Studi Sarjana Teknik Sipil, Universitas Tarumanagara, Jl. Letjen S. Parman No.1 Jakarta \\ Email:alfredsusilo@gmail.com
}

\begin{abstract}
ABSTRAK
Fondasi tiang pada umumnya digunakan untuk pembangunan gedung bertingkat dan dalam perencanaannya, beban yang lebih mempengaruhi fondasi adalah beban lateral dibandingkan beban aksial. Tanah lunak tidak dapat memberikan daya dukung baik lateral maupun aksial yang besar, sehingga tanah lunak membutuhkan perlakuan khusus seperti perbaikan tanah. Salah satu cara memperbaiki tanah lunak adalah dengan cara grouting. Tujuan dilakukannya grouting untuk membuat tanah menjadi padat dengan mengisi bahan mortar sehingga daya dukung lateral dapat meningkat. Metode p-y yang diusulkan Reese et al., adalah salah satu metode yang dapat digunakan untuk menganalisis fondasi tiang yang dibebani secara lateral pada jenis tanah pasir. Analisis juga menggunakan bantuan program yang sering digunakan untuk menganalisis beban lateral pada tiang. Fondasi tiang dianalisis dalam 2 kondisi, yaitu sebelum dan setelah dilakukan grouting dan membandingkan daya dukung lateral 2 kondisi tersebut sehingga diperoleh efektivitas kedalaman grouting.
\end{abstract}

Kata kunci: fondasi tiang, grouting, daya dukung lateral, tanah lunak, $p$-y curve

\section{PENDAHULUAN}

\section{Latar belakang}

Keterbatasan lahan di DKI Jakarta mengakibatkan maraknya pembangunan gedung bertingkat (high-rise building). Pembangunan gedung bertingkat (high-rise building) pada umumnya menggunakan jenis fondasi tiang. Dalam mendesain fondasi tiang, beban yang harus diperhitungkan adalah beban aksial dan beban lateral. Untuk high-rise building yang sangat tinggi dan memiliki ukuran lebar dan panjang bangunannya berbeda terlalu jauh sehingga bisa disebut sebagai bangunan langsing, beban lateral yang lebih menentukan pada bangunan jenis ini. Beban lateral dapat berupa tekanan angin, gaya geser seismik, dan lain-lain. Sehingga dalam mendesain gedung bertingkat khususnya bangunan yang sangat tinggi dan langsing, dibutuhkan tanah yang dapat memberikan daya dukung lateral yang besar pada tiang.

Tanah lunak tidak dapat memberikan daya dukung baik aksial maupun lateral yang besar tanpa perlakuan khusus, seperti perbaikan tanah. Salah satu cara perbaikan tanah lunak adalah dengan cara grouting. Menurut Udiana (2013), injeksi semen atau sementasi (grouting) adalah proses memasukan suatu bahan berupa semen dan air dengan tekanan ke dalam rongga atau pori, rekahan dan retakan batuan sehingga dalam waktu tertentu akan menjadi padat dan keras secara fisika maupun kimiawi.

Menurut Warner (2004), tipe-tipe grouting antara lain: sementasi penembusan (permeation grouting), sementasi kompaksi (compaction grouting), sementasi rekahan (fracture grouting), sementasi campuran/jet (mixing/jet grouting), sementasi isi (fill grouting), sementasi vakum (vaccum grouting). Permeation grouting berfungsi untuk mengisi retakan, rekahan, atau kerusakan pada batuan, beton maupun rongga pori pada tanah, agregat atau media pori lainnya.

Tanjung Priok berada pada bagian utara DKI Jakarta yang terkenal akan pelabuhannya, adalah salah satu daerah yang memiliki tanah lunak di DKI Jakarta yang membutuhkan perbaikan tanah. Sebagian besar tanah di daerah Tanjung Priok adalah tanah lunak yang berpasir sehingga dapat digunakan sebagai bahan penelitian. 


\section{Batasan masalah}

Dalam penelitian ini, batasan-batasan yang digunakan sebagai berikut:

1. Hanya menganalisa kapasitas daya dukung lateral fondasi tiang dengan menggunakan metode $p-y$ dan bantuan program

2. Menggunakan fondasi tiang pancang dengan ukuran $40 \mathrm{x} 40 \mathrm{~cm}$ dengan spesifikasi yang didapat dari brosur Adhi Beton, sedalam 24 meter sesuai dengan parameter tanah yang digunakan

3. Menggunakan kepala tiang bebas (free head)

4. Hanya menggunakan tipe sementasi penembusan (permeation grouting) dengan bahan material berupa campuran adukan semen dan air

5. Hanya melakukan penelitian dengan data tanah di daerah Tanjung Priok

6. Hanya memperhitungkan beban gravitasi untuk fondasi tiang, beban akibat gempa tidak diperhitungkan

7. Radius grouting tidak diperhitungkan dan diasumsikan radius grouting sebesar 2 kali lebar tiang di sekitar fondasi tiang

8. SNI yang digunakan sebagai acuan adalah SNI Persyaratan Perancangan Geoteknik (SNI 8640-2017)

\section{Rumusan masalah}

Rumusan masalah yang akan dibahas pada penelitian ini:

1. Analisis efektivitas kedalaman grouting pada tanah lunak di daerah Tanjung Priok

2. Pengaruh perbaikan tanah dengan melakukan grouting pada tanah lunak di daerah Tanjung Priok terhadap peningkatan daya dukung lateral fondasi tiang.

\section{Tujuan penelitian}

Beberapa tujuan dari penelitian ini adalah:

1. Untuk mengetahui efektivitas kedalaman grouting pada tanah lunak di daerah Tanjung Priok dengan menggunakan bantuan analisis program dan metode $p-y$ curve

2. Untuk mengetahui peningkatan daya dukung lateral pada fondasi tiang akibat perbaikan tanah dengan melakukan sistem grouting pada tanah lunak di daerah Tanjung Priok dengan menggunakan metode $p-y$ dan bantuan analisis program.

\section{Manfaat penelitian}

Penelitian ini diharapkan dapat memberikan manfaat sebagai berikut:

1. Berguna sebagai sumbangan pemikirian mengenai salah satu opsi dalam memperbaiki tanah

2. Berguna sebagai salah satu referensi bagi para pembaca khususnya para mahasiswa dan masyarakat yang akan melakukan penelitan mengenai tanah yang berhubungan dengan teknik sipil

\section{Grouting}

Menurut Dwiyanto, 2005 (dalam Ardiaristi dan Yanuardy, 2010), grouting merupakan metode untuk memperkuat tanah dan memperkecil permeabilitas tanah dengan cara menginjeksi semen atau bahan kimia ke dalam lapisan tanah.

Perbaikan tanah dengan menggunakan sistem grouting dapat meningkatkan daya dukung seperti dalam penelitian Asbella (2014), grouting yang dilakukan meningkatkan nilai N-SPT, sehingga efektivitas yang didapatkan dari perbandingan nilai N-SPT sebelum dan sesudah grouting adalah sekitar 150\% hingga $200 \%$.

Dengan perbaikan menggunakan sistem grouting, maka tanah dapat memberikan daya dukung baik aksial dan lateral yang besar kepada fondasi.

\section{Fondasi tiang}

Menurut Coduto, Kitch, dan Yeung (2016), fondasi dalam terbagi menjadi 3, yaitu piles, caissons, pile-supported. Fondasi tiang (piles) adalah fondasi yang paling umum digunakan. Bahan fondasi tiang dapat menggunakan bambu, kayu, beton, dan baja.

Fondasi dapat menahan beban aksial dan beban lateral. Beban aksial adalah beban yang bekerja secara vertikal dan berasal dari beban bangunan berupa gaya tarik dan tekan. Beban lateral adalah beban yang bekerja secara horizontal. Beban lateral berasal dari tekanan tanah lateral, tekanan air, beban angin, dan beban gempa sehingga menyebabkan gaya gesser dan momen pada tiang, Beban lateral dapat menyebabkan defleksi pada tiang. (Coduto, Kitch dan Yeung, 2016) 


\section{Metode $p$-y curve}

Untuk menganalisis defleksi lateral pada tiang terdapat beberapa metode yang dapat digunakan antara lain, metode $p-y$. Metode $p-y$ adalah salah satu metode untuk menganalisis fondasi tiang yang dibebani secara lateral. Untuk penelitian ini, digunakan metode $p-y$ yang diusulkan oleh Reese et al., pada tahun 1974 untuk menganalisis defleksi lateral tiang dengan jenis tanah pasir dan dibandingkan dengan hasil analisis metode elemen hingga. Seperti Elfaaz dan Hamdan (2016), yang menggunakan metode $p-y$ yang diusulkan oleh Reese Matlock dan membandingkannya dengan hasil analisis metode elemen hingga. Salah satu kesimpulan dari penelitian mereka adalah sudut geser dalam $(\varnothing)$ merupakan parameter yang paling berpengaruh dalam meningkatkan daya dukung lateral fondasi tiang.

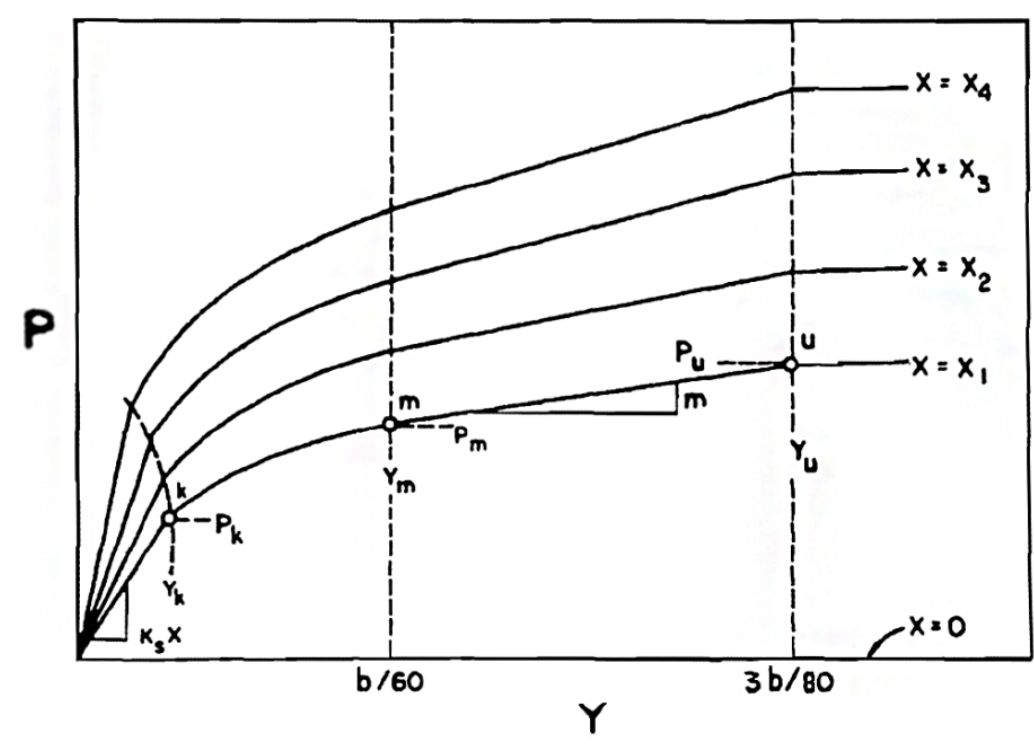

Gambar 1. Bentuk karakteristik $p-y$ curve dengan beban statik pada tanah pasir oleh Reese et al., pada tahun 1974 (Reese et al, 2006)

Persamaan daya dukung ultimate pada tanah yang berada di dekat permukaan tanah adalah sebagai berikut:

$$
p_{s t}=\gamma z\left[\frac{k_{o} z \tan \phi \sin \beta}{\tan (\beta-\phi) \cos \alpha}+\frac{\tan \beta}{\tan (\beta-\phi)}(b+z \tan \beta \tan \alpha)+k_{o} \tan \beta(\tan \phi \sin \beta-\tan \alpha)-k_{a} b\right]
$$

Persamaan daya dukung ultimate dengan kedalaman tertentu dibawah perbukaan tanah adalah sebagai berikut:

$$
p_{s t}=k_{a} \mathrm{~b} \gamma z\left(\tan ^{8} \beta-1\right)+k_{o} \mathrm{~b} \gamma z \tan \phi \tan ^{4} \beta
$$

Dimana:

$$
\begin{aligned}
& k_{o}=1-\sin \varphi \\
& k_{a}=\tan ^{2}\left(45-\frac{\varphi}{2}\right) \\
& \propto=\frac{\varphi}{2} \\
& \beta=45+\frac{\varphi}{2}
\end{aligned}
$$

Titik-titik pada $p$-y curve ini adalah persamaan $\mathrm{p}_{\mathrm{k}}, \mathrm{y}_{\mathrm{k}} ; \mathrm{p}_{\mathrm{m}}, \mathrm{y}_{\mathrm{m}}$ dan $\mathrm{p}_{\mathrm{u}}, \mathrm{y}_{\mathrm{u}}$. Koordinat $\mathrm{p}_{\mathrm{m}}, \mathrm{y}_{\mathrm{m}} \mathrm{dan} \mathrm{p}_{\mathrm{u}}, \mathrm{y}_{\mathrm{u}}$ dipengaruhi oleh faktor penyesuaian empiris dan lebar tiang. Nilai $\mathrm{p}_{\mathrm{u}}$ dan $\mathrm{p}_{\mathrm{m}}$ adalah sebagai berikut:

$$
\begin{aligned}
& y_{u}=3 b / 80 \\
& p_{u}=A_{s} p_{s} \\
& y_{m}=b / 60 \\
& p_{m}=B_{s} p_{s}
\end{aligned}
$$


A

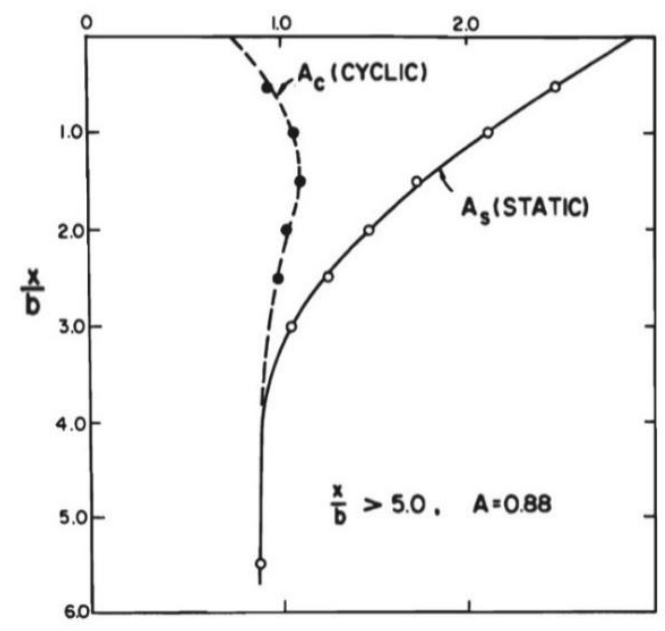

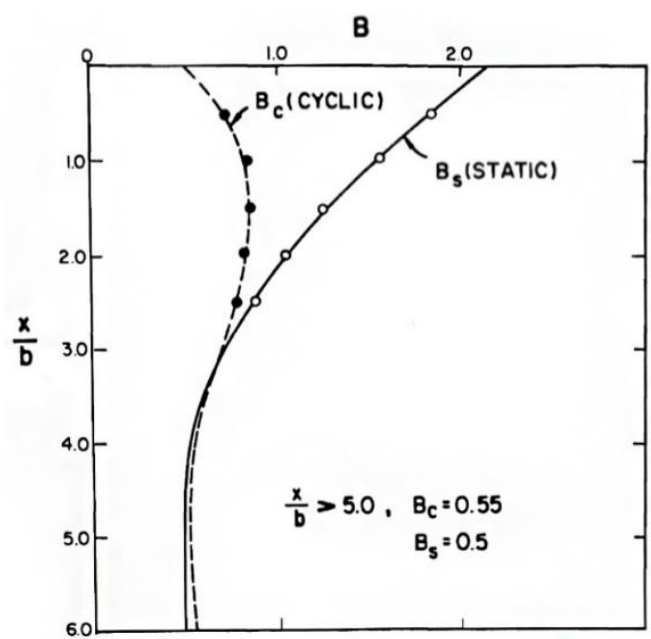

Gambar 2. Nilai koefisien A (kiri) dan nilai koefisien B (kanan) (Reese et al, 2006)

Persamaan garis awal lurus kurva adalah sebagai berikut:

$$
p=k_{p y} z y
$$

Dimana nilai $\mathrm{k}_{\mathrm{py}}$ diambil dari tabel 1 .

Tabel 1. Nilai $\mathrm{k}_{\mathrm{py}}$ untuk jenis tanah pasir (Reese, Isenhower, dan Wang, 2006)

\begin{tabular}{c|c|c|c}
\hline Relative Density of Sand & Loose & Medium & Dense \\
\hline \multicolumn{4}{c|}{ Submerged Sand } \\
\hline $\mathrm{K}_{\mathrm{py}}\left(\mathrm{MN} / \mathrm{m}^{3}\right)$ & 5.4 & 16.3 & 34 \\
\hline \multicolumn{4}{c}{ Sand Above Water Table } \\
\hline $\mathrm{K}_{\mathrm{py}}\left(\mathrm{MN} / \mathrm{m}^{3}\right)$ & 6.8 & 24.4 & 61 \\
\hline
\end{tabular}

p-y curve berbentuk parabola dimulai dari titik $\mathrm{p}_{\mathrm{k}}, \mathrm{y}_{\mathrm{k}}$ hingga titik $\mathrm{p}_{\mathrm{m}}, \mathrm{y}_{\mathrm{m}}$. Persamaan kurva parabola tersebut adalah sebagai berikut:

$$
p=c y^{1 / \mathrm{n}}
$$

Untuk mencari kemiringan garis antara titik $y_{m}$ dan titik $y_{u}$, digunakan persamaan sebagai berikut:

$$
m=\frac{p_{u}-p_{m}}{y_{u}-y_{m}}
$$

Untuk mencari konstanta $\mathrm{n}$ dan c, digunakan persamaan sebagai berikut:

$$
\begin{aligned}
& n=\frac{p_{m}}{m y_{m}} \\
& c=\frac{p_{m}}{y_{m}{ }^{1 / n}}
\end{aligned}
$$

Untuk mencari nilai titik $\mathrm{y}_{\mathrm{k}}$, digunakan persamaan sebagai berikut:

$$
y_{k}=\left(\frac{c}{k_{p y}}\right)^{\frac{n}{n-1}}
$$

Untuk mencari nilai $\mathrm{p}_{\mathrm{k}}$, digunakan persamaan sebagai berikut:

$$
p_{k}=k_{p y} z y
$$


dengan $\gamma^{\prime}=$ Berat isi rata-rata tanah dari permukaan tanah ke $p$-y curve $\left[\mathrm{kN} / \mathrm{m}^{3}\right], \gamma=$ Berat isi tanah dari permukaan tanah ke $p$-y curve $\left[\mathrm{kN} / \mathrm{m}^{3}\right], \mathrm{z}=$ Kedalaman $p$-y curve $[\mathrm{m}], \mathrm{c}=$ Kuat geser tidak terdrainase rata-rata pada kedalaman $\mathrm{z}\left[\mathrm{kN} / \mathrm{m}^{2}\right], \mathrm{b}=$ Diameter atau lebar tiang $[\mathrm{m}], \mathrm{J}=0.5$ untuk lempung lunak dan 0.25 untuk lempung sedang, $p_{u}=$ Daya dukung tanah ultimate $[\mathrm{kN} / \mathrm{m}], p=$ Daya dukung tanah $[\mathrm{kN} / \mathrm{m}], y=$ Defleksi tiang $[\mathrm{mm}], k_{p y}=$ Modulus reaksi tanah awal $\left[\mathrm{kN} / \mathrm{m}^{3}\right], k_{a} \quad=$ Koefisien tekanan tanah aktif minimum, $k_{o}=$ Koefisien tekanan tanah saat istirahat, $\mathrm{A}_{\mathrm{s}}=$ Koefisien untuk pembebanan statis, $\emptyset=$ Sudut geser dalam $\left[{ }^{\circ}\right]$

\section{METODOLOGI PENELITIAN}

\section{Metode pengumpulan data}

Metode yang digunakan untuk pengumpulan data penelitian ini adalah teknik dokumentasi yaitu pengumpulan data dari proyek. Pada penelitian ini, data tanah yang dianalisis berlokasi pada daerah Tanjung Priok, Jakarta Utara. Data tanah berupa boring log sedalam 30 meter dan hasil tes laboratorium.

\section{Metode analisis data}

Sebelum dilakukannya analisis, perlu dilakukan studi literatur dengan mencari dasar-dasar teori dan sumber data seperti jurnal, buku referensi untuk mendapatkan rumus-rumus dalam menghitung daya dukung lateral fondasi tiang. Metode analisis yang digunakan untuk menganalisa data menggunakan program berbasis metode elemen hingga dan metode $p-y$ curve yang diusulkan oleh Reese et al. Analisis akan dilakukan dalam 2 kondisi, sebelum dan setelah perbaikan tanah dengan grouting serta akan dilakukan perubahan kedalaman grouting untuk menentukan keefektivitasnnya. Hasil analisis berupa kurva p-y ( $p-y$ curve) dengan berbagai kedalaman. Dengan hasil $p-y$ curve akan dilakukan perbandingan daya dukung lateral fondasi tiang sebelum dan setelah perbaikan dan diperoleh peningkatan daya dukung lateral fondasi tiang yang dipengaruhi oleh kedalaman perbaikan tanah dengan sistem grouting.

\section{ANALISIS DAN PEMBAHASAN}

\section{Kesimpulan parameter tanah}

Berdasarkan data analisis laboratorium, lapangan dan hasil korelasi, dapat dianalisis untuk mendapatkan pembagian lapisan tanah. Berikut merupakan kesimpulan parameter yang digunakan untuk analisis perhitungan menggunakan metode $p$ - $y$ curve dan analisis program.

Tabel 2. Rangkuman parameter yang digunakan sebelum digrouting

\begin{tabular}{|c|c|c|c|c|c|c|c|c|c|c|c|c|}
\hline $\begin{array}{l}\text { Kedalaman } \\
\quad(\mathrm{m})\end{array}$ & Jenis Tanah & $\begin{array}{l}\text { N-SPT } \\
(\mathrm{N}- \\
\text { Value }) \\
\end{array}$ & $\mathrm{e}$ & $\begin{array}{c}\text { Gs } \\
\left(\mathrm{T} / \mathrm{m}^{3}\right)\end{array}$ & $\begin{array}{c}\gamma_{\text {wet }} \\
\left(\mathrm{kN} / \mathrm{m}^{3}\right)\end{array}$ & $\begin{array}{c}\gamma_{\mathrm{sat}} \\
\left(\mathrm{kN} / \mathrm{m}^{3}\right)\end{array}$ & $\begin{array}{c}\gamma^{\prime} \\
\left(\mathrm{kN} / \mathrm{m}^{3}\right)\end{array}$ & $\begin{array}{l}\emptyset \\
\left({ }^{\circ}\right)\end{array}$ & $\underset{\left(\mathrm{kN} / \mathrm{m}^{2}\right)}{\mathrm{Su}}$ & $\begin{array}{c}\mathrm{C}^{\prime} \\
\left(\mathrm{kN} / \mathrm{m}^{2}\right)\end{array}$ & $\varepsilon_{50}$ & $\begin{array}{c}\mathrm{k}_{\mathrm{py}} \\
\left(\mathrm{MN} / \mathrm{m}^{3}\right)\end{array}$ \\
\hline $0-1$ & Loose Sand & 7 & 0.8 & 26.6 & 17 & 17 & 7 & 30.5 & 45 & N/A & N/A & 5.4 \\
\hline $1-3$ & Loose Sand & 8 & 0.7 & 26.6 & 17 & 17 & 7 & 30 & 40 & N/A & N/A & 5.4 \\
\hline $3-4$ & Loose Sand & 10 & 0.95 & 26.6 & 17 & 17 & \multicolumn{2}{|c|}{$\begin{array}{c}7 \\
31\end{array}$} & 51 & N/A & N/A & 5.4 \\
\hline $4-10$ & Soft Silty Clay & 7 & 1.65 & 27.6 & 27.6 & 16.5 & 6.5 & 24 & 40 & 8 & 0.02 & 135 \\
\hline $10-16$ & $\begin{array}{l}\text { Very Soft Clayey } \\
\text { Silt }\end{array}$ & 4 & 2.24 & 26.6 & 15 & 15.5 & 5.5 & 20 & 55 & 11 & 0.02 & 135 \\
\hline $16-20$ & $\begin{array}{l}\text { Medium Stiff } \\
\text { Clay }\end{array}$ & 9 & 0.9 & 26.6 & 15 & 18 & 8 & 22 & 100 & 20 & 0.01 & 135 \\
\hline $20-24$ & Very Stiff Silt & 10 & 0.65 & 26.6 & 15 & 20 & 10 & 29 & 125 & 25 & 0.005 & 270 \\
\hline $24-28$ & $\begin{array}{l}\text { Hard Silt } \\
\text { (Cemented Silt) }\end{array}$ & 58 & 0.6 & 26.6 & 15 & 20.3 & 10.3 & 31 & 140 & 28 & 0.004 & 270 \\
\hline $28-30$ & $\begin{array}{l}\text { Very Dense Sand } \\
\text { (Cemented } \\
\text { Sand) }\end{array}$ & 60 & 0.55 & 26.6 & 15 & 20.7 & 10.7 & 36 & 150 & N/A & N/A & 34 \\
\hline
\end{tabular}

$\mathrm{N} / \mathrm{A}=$ tidak dapat dipakai 
Analisis Efektivitas Kedalaman Grouting untuk Fanica, et al. Meningkatkan Daya Dukung Lateral Fondasi Tiang Beton Pracetak

Tabel 3. Parameter perbaikan tanah dengan grouting sedalam 4 meter

\begin{tabular}{|c|c|c|c|c|c|c|c|}
\hline \multirow{2}{*}{$\begin{array}{l}\text { Kedalaman } \\
\text { (m) }\end{array}$} & \multirow{2}{*}{ Jenis Tanah } & \multicolumn{3}{|c|}{ Parameter Tanah Awal } & \multicolumn{3}{|c|}{ Parameter Tanah Perbaikan } \\
\hline & & $\begin{array}{c}\mathrm{N}-\mathrm{SPT} \\
(\mathrm{N}-\text { Value })\end{array}$ & $\begin{array}{l}\emptyset \\
\left({ }^{\circ}\right)\end{array}$ & $\begin{array}{c}\mathrm{k}_{\mathrm{py}} \\
\left(\mathrm{MN} / \mathrm{m}^{3}\right)\end{array}$ & $\begin{array}{c}\mathrm{N}-\mathrm{SPT} \\
(\mathrm{N}-\text { Value })\end{array}$ & $\begin{array}{c}\emptyset \\
\left({ }^{\circ}\right)\end{array}$ & $\begin{array}{c}\mathrm{k}_{\mathrm{py}} \\
\left(\mathrm{MN} / \mathrm{m}^{3}\right)\end{array}$ \\
\hline $0-1$ & \multirow{4}{*}{$\begin{array}{l}\text { Pasir Lepas } \\
\text { (Loose Sand) }\end{array}$} & 7 & 30.5 & 5.4 & 14 & 33 & 16.3 \\
\hline $1-2$ & & 8 & 30 & 5.4 & 16 & 34 & 16.3 \\
\hline $2-3$ & & 8 & 30 & 5.4 & 12 & 32 & 16.3 \\
\hline $3-4$ & & 10 & 31 & 5.4 & 15 & 33 & 16.3 \\
\hline
\end{tabular}

\section{Hasil perhitungan p-y curve berdasarkan metode Reese et al., (1974)}

Garis parabola penghubung titik $\mathrm{y}_{\mathrm{k}}, \mathrm{p}_{\mathrm{k}}$ dan titik $\mathrm{y}_{\mathrm{m}}, \mathrm{p}_{\mathrm{m}}$ menggunakan nilai defleksi (y) dengan interval $0.0005 \mathrm{~m}$ atau $5 \mathrm{~mm}$ untuk memudahkan perhitungan.

Hasil perhitungan $p$-y curve dengan kondisi sebelum dan setelah perbaikan menggunakan grouting pada kedalaman 1 meter hingga 4 meter dari permukaan tanah diplot sehingga membentuk grafik seperti gambar 3 dan 4.

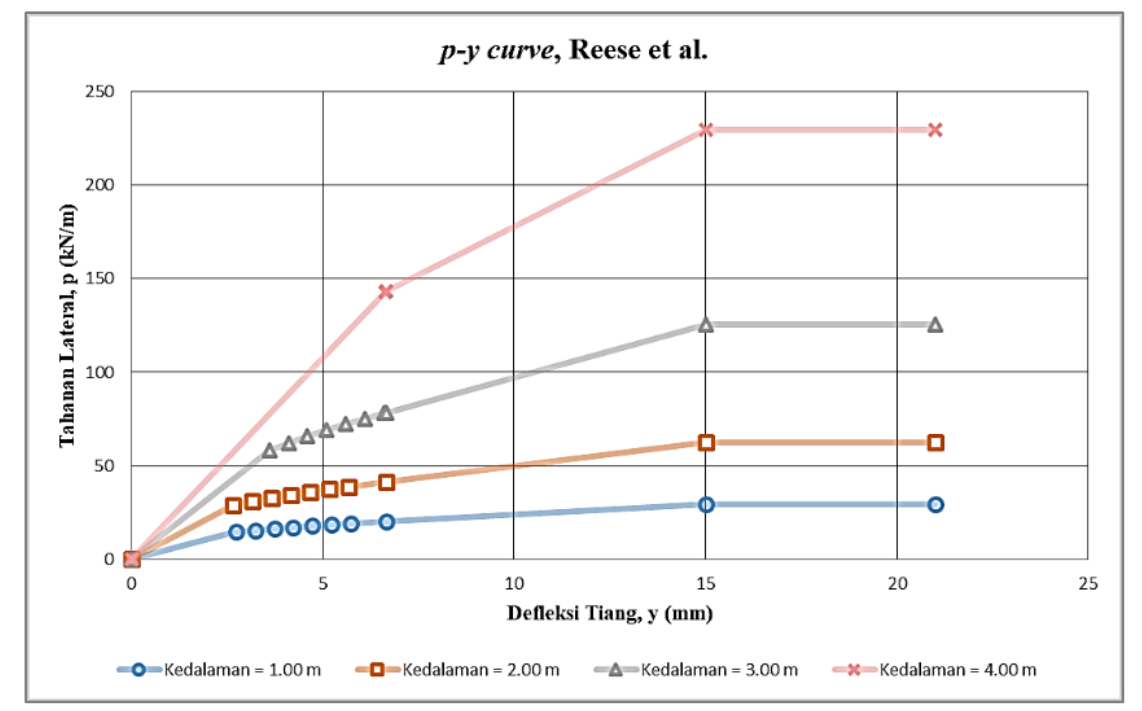

Gambar 3. Hasil p-y curve menggunakan metode Reese et al., (1974) dengan kondisi sebelum grouting 


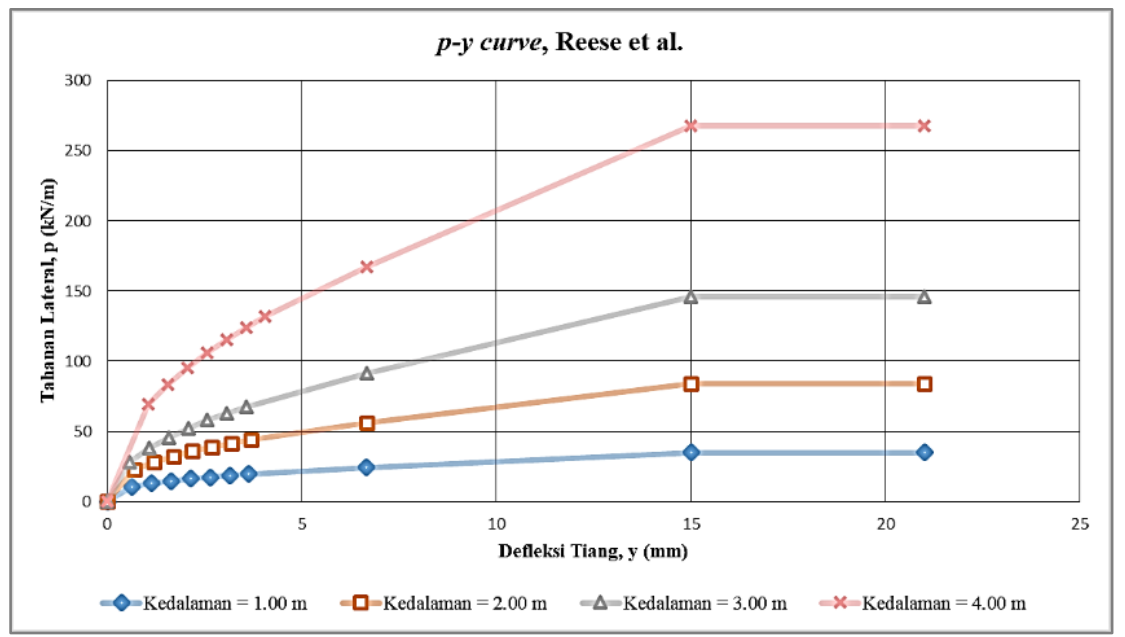

Gambar 4. Hasil p-y curve menggunakan metode Reese et al., (1974) dengan kondisi setelah grouting

\section{Hasil perhitungan $p$-y curve menggunakan bantuan analisis program}

Hasil perhitungan $p$-y curve dengan kondisi sebelum dan setelah perbaikan menggunakan grouting diplot sehingga membentuk grafik seperti gambar 5 dan 6.

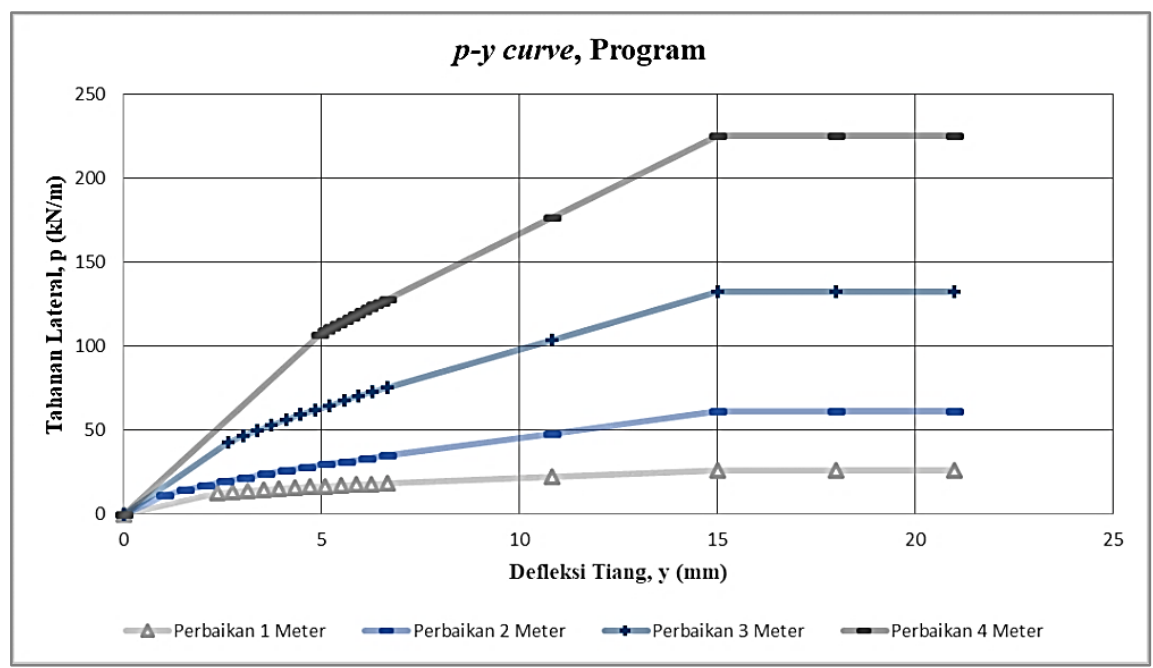

Gambar 5. Hasil p-y curve dengan kondisi sebelum grouting menggunakan bantuan analisis program 


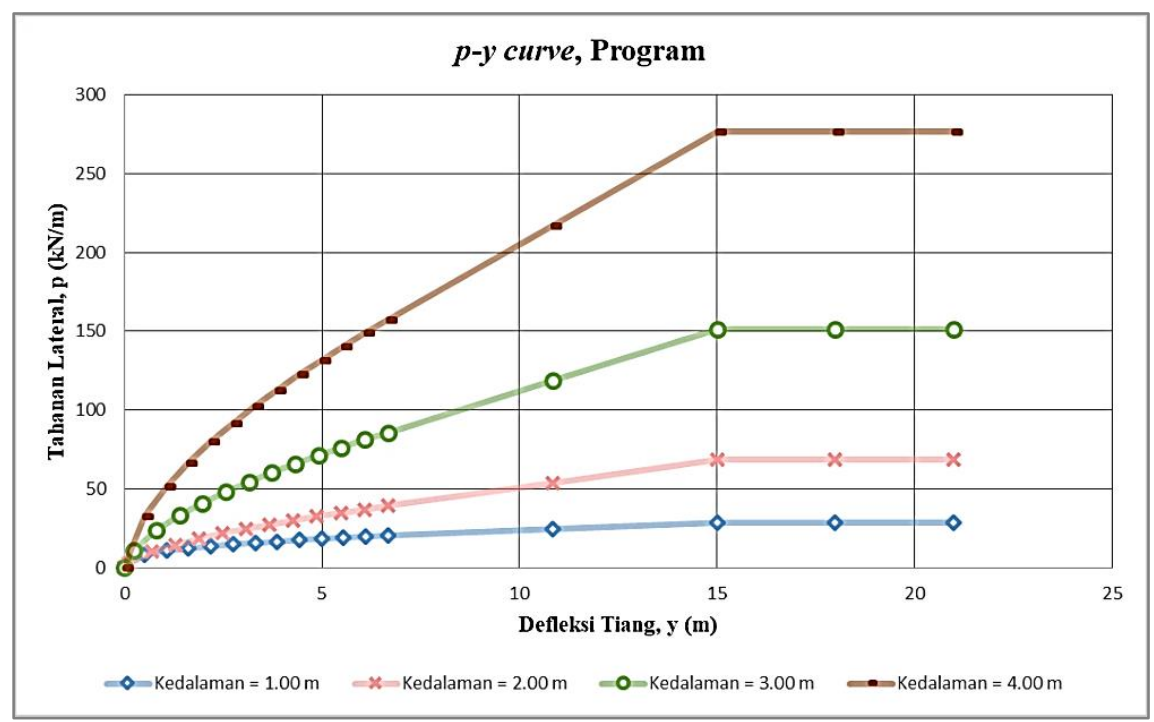

Gambar 6 Hasil p-y curve dengan kondisi setelah grouting menggunakan bantuan analisis program

\section{Perbandingan tahanan lateral sebelum dan setelah grouting}

Berdasarkan SNI Persyaratan Perancangan Geoteknik (SNI 8460-2017), lendutan ijin lateral tiang sebesar 1/2 inci atau $12 \mathrm{~mm}$. Untuk perbandingan $p$-y curve digunakan safety factor sebesar 2 sehingga lendutan ijin lateral yang digunakan sebesar $1 / 4$ inci atau $6.35 \mathrm{~mm}$. Nilai tahanan lateral (p) tiap meter didapatkan dengan cara interpolasi. Selisih tahanan lateral sebelum dan setelah grouting akan ditampilkan dalam bentuk persentase.

\section{Perbandingan $p$-y curve sesuai dengan kedalaman perbaikan tanah}

Nilai tahanan lateral dari $p-y$ curve ditinjau sesuai dengan kedalaman perbaikan. Jika perbaikan tanah 1 meter, maka $p$-y curve ditinjau dengan kedalaman 1 meter, begitu juga untuk perbaikan 2 meter, $p$-y curve ditinjau dengan kedalaman 2 meter dan untuk seterusnya. Perbandingan dilakukan dengan menggunakan 2 nilai tahanan lateral, yaitu dengan perhitungan manual dengan metode Reese et al., dan dengan menggunakan bantuan program.

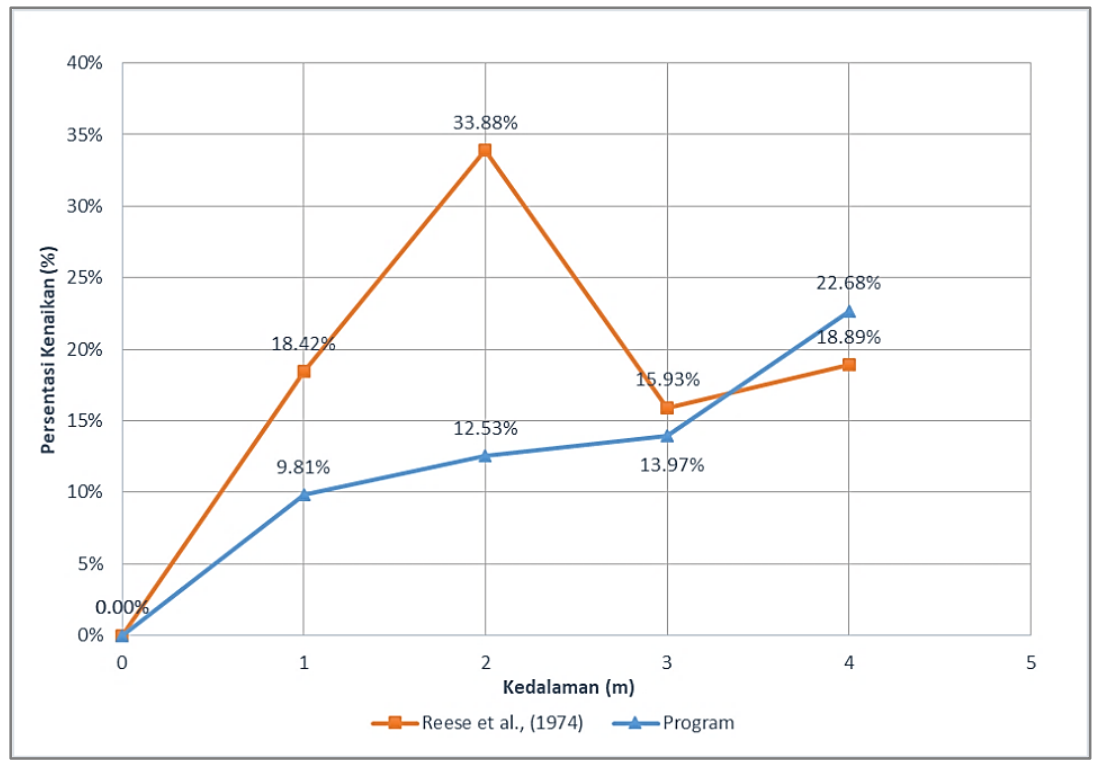

Gambar 7. Persentase perbandingan tahanan lateral sebelum dan setelah grouting dengan metode Reese et al., (1974) dan menggunakan bantuan analisis program 


\section{Perbandingan $p$-y curve dengan kedalaman 1 sampai 4 meter}

Nilai tahanan lateral yang ditinjau pada kedalaman 1 sampai 4 meter merupakan hasil bantuan analisis program untuk kondisi sebelum perbaikan dan kondisi setelah perbaikan dengan kedalaman 1 sampai dengan 4 meter dari permukaan tanah. Perbandingan antara kondisi sebelum perbaikan atau perbaikan 0 meter dengan kondisi perbaikan 1 meter hingga 4 meter menggunakan nilai tahanan lateral yang diperoleh dengan cara interpolasi dengan lendutan ijin sebesar $6.35 \mathrm{~mm}$. Selisih tahanan lateral ditampilkan dalam bentuk persentase seperti pada gambar 8 .

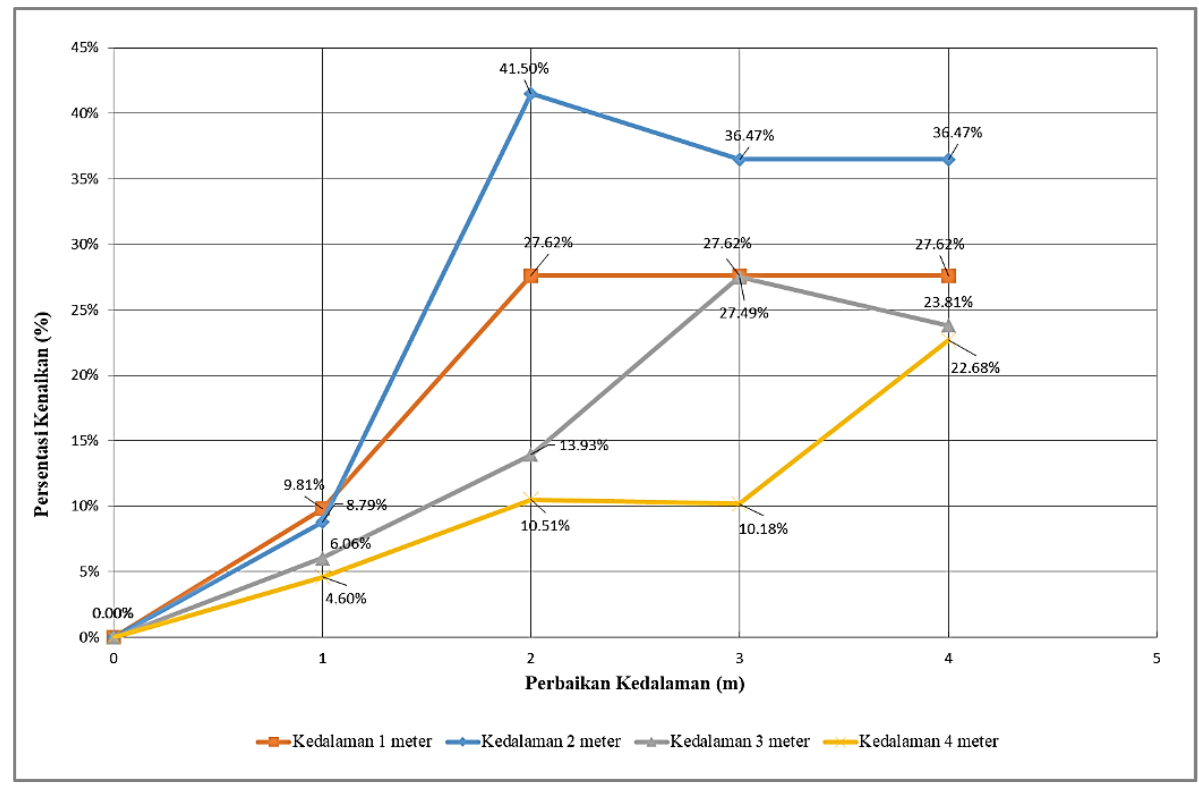

Gambar 8. Persentase kenaikan tahanan lateral pada kedalaman 1 hingga 4 meter

\section{KESIMPULAN}

Dari hasil penelitian yang diperoleh, dapat disimpulkan beberapa hal berikut ini:

1. Terdapat perbedaan perbandingan peningkatan antara metode Reese et al., dan analisis program, perbedaan tersebut mungkin terjadi karena saat menganalisis $p$-y curve dengan kedalaman 3 dan 4 meter, metode Reese et al., (1974) tidak memperhitungkan perubahan parameter pada kedalaman di atasnya, sehingga terjadi penurunan persentase perbandingan tahanan lateral sebelum dan setelah digrouting seperti pada gambar 7.

2. Pada kedalaman 2 meter, parameter sudut geser dalam $(\varnothing)$ diasumsikan meningkat lebih tinggi dibandingkan kedalaman lain, sehingga persentase perbandingan peningkatannya lebih tinggi dibandingkan persentase peningkatan pada kedalaman lain, yaitu sebesar $34.04 \%$ seperti pada gambar 7 .

3. Pada gambar 7, terlihat peningkatan tahanan lateral tertinggi dengan menggunakan bantuan analisis program adalah sebesar $22.68 \%$ yang ditinjau pada kedalaman 4 meter sesuai dengan kedalaman perbaikannya.

4. Perbaikan tanah dengan menggunakan grouting sedalam 1 meter dapat meningkatkan tahanan lateral tiang sebesar $9.82 \%$ pada kedalaman 1 meter dan sebesar $8.79 \%$ pada kedalaman 2 meter, lalu sebesar $6.06 \%$ untuk kedalaman 3 meter, dan yang terakhir adalah sebesar $4.60 \%$ untuk tahanan lateral di kedalaman 4 meter

5. Pada perbaikan tanah sedalam 2 meter, tahanan lateral pada kedalaman 1 meter meningkat sebesar $27.62 \%$, kemudian pada kedalaman 2 meter sebesar 41.50\%, dan pada kedalaman 3 meter sebesar $13.93 \%$ serta untuk kedalaman 4 meter, peningkatan tahanan lateral yang terjadi adalah sebesar $10.51 \%$

6. Untuk perbaikan sedalam 3 meter, tahanan lateral pada kedalaman 1 meter tidak berpengaruh, sehingga grafik kenaikan tahanan lateral bersifat konstan dan perbaikan sedalam 3 meter tidak efektif lagi untuk tahanan lateral pada kedalaman 2 meter, oleh karena itu grafik kenaikan tahanan lateral menurun, seperti pada gambar 8 .

7. Pada perbaikan tanah sedalam 3 meter, tahanan lateral pada kedalaman 3 meter mengalami peningkatan sebesar $27.49 \%$ dan $10.18 \%$ untuk tahanan lateral pada kedalaman 4 meter 
8. Untuk perbaikan tanah sedalam 4 meter, tahanan lateral pada kedalaman 1 dan 2 meter tidak berpengaruh, dan perbaikan tanah sedalam 4 meter tidak efektif untuk tahanan lateral pada kedalaman 3 meter. Hal ini dapat dilihat pada gambar 8 .

9. Pada perbaikan tanah sedalam 4 meter, tahanan lateral pada kedalaman 4 meter mengalami peningkatan sebesar $22.68 \%$

\section{DAFTAR PUSTAKA}

Ardiaristi, B. dan Yanuardy. M. A. (2010). "Metode Grouting untuk Penanggulangan Gerakan Tanah Berdasarkan Jenis Gerakan Tanah dan Analisis Kestabilan Lereng pada Perumahan Bukit Manyaran Permai, Kelurahan Sadeng, Kecamatan Gunung Pati, Semarang-Jawa Tengah”. Teknik Geologi Universitas Diponegoro. Semarang

Asbella, K. A. (2014). "Evaluasi Grouting pada Section Retaining Wall-B (Downstream) di Kali Semarang, Kelurahan Panggung Lor, Kota Semarang, Jawa Tengah". Teknik Geologi Universitas Diponegoro. Semarang

Coduto, D. P., Kitch, W. A., and Yeung M. R. (2016). Foundation Design: Principles and Practices (Third Edition). Pearson. Pomona, California

Dwiyanto, J.S. (2005). "Pelatihan Grouting". Pemerintah Propinsi Jawa Tengah, Dinas Pengelolaan Sumber Daya Air. Semarang

Elfaaz, F. M. dan Hamdhan, I. N. (2016). “Analisis Daya Dukung Lateral Fondasi Tiang Tunggal Menggunakan Metode Elemen Hingga”. Institut Teknologi Nasional. Bandung

Reese, L. C., Isenhower, W. M., Wang, S. (2006). Analysis and Design of Shallow and Deep Foundations. John Wiley \& Sons, Inc. New York

SNI 8460. 2017. Persyaratan Perancangan Geoteknik. Badan Standardisasi Nasional. Jakarta

Udiana, I.M. (2013).’Desain Campuran Semen dan Air pada Pekerjaan Grouting Proyek Bendungan/Waduk Nipah Madura-Jawa Timur". Universitas Nusa Cendana. Kupang

Warner, J. (2004). Practical Handbook of Grouting: Soil, Rock, and Structures. John Wiley \& Sons, Inc. New Jersey 